\title{
Differential recruitment of the coactivator proteins CREB-binding protein and steroid receptor coactivator-1 to peroxisome proliferator-activated receptor gamma/9-cis-retinoic acid receptor heterodimers by ligands present in oxidized low-density lipoprotein
}

\author{
J Wigren, S Surapureddi, A G Olsson , C K Glass², \\ S Hammarström and $M$ Söderström \\ Division of Cell Biology, Department of Biomedicine and Surgery and ${ }^{1}$ Division of Internal Medicine, Department of Internal Medicine and Care, \\ Linköping University, S-58185 Linköping, Sweden \\ ${ }^{2}$ Department of Cellular and Molecular Medicine and Endocrinology and Division of Metabolism, Department of Medicine, University of California San Diego, \\ 9500 Gilman Drive, La Jolla, California 92093-0651, USA \\ (Requests for offprints should be addressed to M Söderström, Cell Biology, IBK, Linköping University, S-581 85, Linköping, Sweden; Email: mats@ibk.liu.se)
}

\begin{abstract}
Peroxisome proliferator-activated receptor gamma $(\operatorname{PPAR} \gamma)$ colocalizes with oxidized low-density lipoprotein (LDL) in foam cells in atherosclerotic lesions. We have explored a potential role of oxidized fatty acids in LDL as PPAR $\gamma$ activators. LDL from patients suffering from intermittent claudication due to atherosclerosis was analyzed using HPLC and gas chromatography/mass spectrophotometry and found to contain 9-hydroxyand 13-hydroxyoctadecadienoic acid (9- and 13-HODE), as well as 5-hydroxy-, 12-hydroxy- and 15hydroxyeicosatetraenoic acid (5-, 12- and 15-HETE respectively). PPAR $\gamma$ was potently activated by $13(\mathrm{~S})-$ HODE and 15(S)-HETE, as judged by transient transfection assays in macrophages or CV-1 cells. 5(S)- and 12(S)-HETE as well as 15 -deoxy- $\Delta^{12,14}$-prostaglandin $\mathrm{J}_{2}$
\end{abstract}

also activated PPAR $\gamma$ but were less potent. Interestingly, the effect of the lipoxygenase products 13(S)-HODE and 15(S)-HETE as well as of the drug rosiglitazone were preferentially enhanced by the coactivator CREB-binding protein, whereas the effect of the cyclooxygenase product 15 -deoxy- $\Delta^{12,14}$-prostaglandin $\mathrm{J}_{2}$ was preferentially enhanced by steroid receptor coactivator- 1 . We interpret these results, which may have relevance to the pathogenesis of atherosclerosis, to indicate that the lipoxygenase products on the one hand and the cyclooxygenase product on the other exert specific effects on the transcription of target genes through differential coactivator recruitment by PPAR $\gamma / 9$-cis retinoic acid receptor heterodimer complexes.

Journal of Endocrinology (2003) 177, 207-214

\section{Introduction}

Peroxisome proliferator-activated receptors (PPARs) are members of the steroid hormone receptor superfamily, and belong to a subgroup that comprises the thyroid hormone receptor, all-trans retinoic acid receptor, 9-cis retinoic acid receptor (RXR), vitamin $\mathrm{D}_{3}$ receptor and several orphan receptors (Glass 1994). Three mammalian PPAR isotypes (PPAR $\alpha$, PPAR $\delta$ (NUC-1) and PPAR $\gamma$ ) have been cloned (Green 1995). PPARs regulate genes encoding enzymes involved in lipid metabolism and probably play an important role in lipid homeostasis. They are activated by long-chain fatty acids and a group of structurally diverse substances termed peroxisome proliferators. Antidiabetic thiazolidinediones and 15 -deoxy- $\Delta^{12,14}$-prostaglandin $\mathrm{J}_{2}$ $\left(15-\right.$ deoxy- $\left.-\Delta^{12,14}-\mathrm{PGJ}_{2}\right)$ bind specifically to PPAR $\gamma$ and promote terminal differentiation of preadipocytes (Forman et al. 1995, Kliewer et al. 1995). The latter compound is a metabolite of prostaglandin $\mathrm{D}_{2}\left(\mathrm{PGD}_{2}\right)$ (Fitzpatrick \& Wynalda 1983, Kikawa et al. 1984) and it has been suggested to be a natural PPAR $\gamma$ ligand (Forman et al. 1995, Kliewer et al. 1995). It has not yet been demonstrated, however, that adipocytes produce $\mathrm{PGD}_{2}$, a precursor of $15-$ deoxy- $-\Delta^{12,14}-\mathrm{PGJ}_{2}$. $\mathrm{PGD}_{2}$ is, on the other hand, a major arachidonic acid metabolite in macrophages (McGuire et al. 1985). Earlier investigations (Ricote et al. 1998b) have shown that expression of PPAR $\gamma$ is increased in activated macrophages and that this receptor attenuates certain macrophage functions (Jiang et al. 1998). Moreover, it was found (Nagy et al. 1998) that PPAR $\gamma$ is activated by oxidized low-density lipoprotein (LDL) and two hydroxy acids, 9- and 13-hydroxyoctadecadienoic acid (HODE), and recent work has demonstrated that lysophosphatidic acid binds to and activates PPAR $\gamma$ 
(McIntyre et al. 2003). HODEs have positive effects on the expression of inflammatory surface markers such as CD36 and CD14 (Nagy et al. 1998, Tontonoz et al. 1998). The gene for CD36, a scavenger receptor that enables the ingestion of oxidized LDL, contains a direct repeat-1 (DR-1) element that is recognized by the PPAR $\gamma / \mathrm{RXR} \alpha$ heterodimer (Tontonoz et al. 1998). It has been noted that 15 -deoxy- $\Delta^{12,14}-\mathrm{PGJ}_{2}$ in combination with the $\mathrm{RXR} \alpha-$ specific ligand LG268 (Boehm et al. 1995) acts through the CD36 promoter DR-1 element to stimulate CD36 expression (Nagy et al. 1998). In addition, it was observed (Ricote et al. 1998a) that PPAR $\gamma$ is expressed in foam cells from human atherosclerotic lesions. Thus PPAR $\gamma$ ligands may play a role in the pathogenesis of atherosclerosis. We performed experiments to determine the endogenous content of selected monohydroxy acids in LDL isolated from a group of patients diagnosed with intermittent claudication and noted the presence of 9- and 13-HODE as well as of 5-hydroxy-, 12-hydroxy- and 15hydroxyeicosatetraenoic acid (5-, 12- and 15-HETE respectively). Transient transfection assays, demonstrated that 13(S)-HODE and 15(S)-HETE, in particular, are potent $\operatorname{PPAR} \gamma$ activators in macrophages. Interestingly, the lipoxygenase products 13(S)-HODE and 15(S)-HETE appeared to induce preferential interaction of PPAR $\gamma /$ RXR $\alpha$ heterodimers with CREB-binding protein (CBP), whereas the cyclooxygenase product 15 -deoxy- $\Delta^{12,14}$ $\mathrm{PGJ}_{2}$ apparently induced interaction of PPAR $\gamma / \mathrm{RXR} \alpha$ with steroid receptor coactivator (SRC)-1.

\section{Materials and Methods}

\section{Chemicals}

The following commercial sources were used: eicosanoids and HODEs, Cayman, Ann Arbor, MI, USA; silicic acid (Biosil HA), BioRad, Richmond, CA, USA; platinum dioxide, Aldrich Chemical Co., Milwaukee, WI, USA; N-bis-trimethylsilyltrifluoroacetamide, Supelco, Bellefonte, PA, USA; restriction enzymes, Life Technologies; $\left[{ }^{35} \mathrm{~S}\right]$ methionine, Amersham; reduced glutathione (GSH)Sepharose, Pharmacia Biotech; luciferin, BioOrbit, Turku, Finland; and LG69, Ligand Pharmaceuticals, San Diego, CA, USA. All other chemicals were purchased from Sigma. Rosiglitazone was a gift from GlaxoSmith Kline.

\section{Cell culture}

RAW 264.7 murine macrophages obtained from the American Type Culture Collection (Rockville, MD, USA) were cultured in high-glucose Dulbecco's modified Eagle's medium (DMEM; Gibco, New York, NY, USA) supplemented with $10 \%$ fetal calf serum (Gibco), $50 \mathrm{U} / \mathrm{ml}$ penicillin and $50 \mu \mathrm{g} / \mathrm{ml}$ streptomycin in an atmosphere containing 8\% $\mathrm{CO}_{2}$. CV-1 cells were cultured in low-glucose DMEM in an atmosphere containing 5\% $\mathrm{CO}_{2}$.

\section{Analysis of LDL monohydroxy acids}

LDL was prepared from venous blood (Havel et al. 1955) drawn from eight males, aged 45-65 years, with intermittent claudication, a condition characterized by atherosclerotic lesions of iliac and femoral arteries. The patients were recruited from a health-screening activity involving more than 20000 participants in the city of Linköping, Sweden. Specific questions were asked regarding symptoms of intermittent claudication. The diagnosis was confirmed by physiological tests (e.g. ankle-brachial blood pressure and treadmill tests). The patients had given informed consent and the study was approved by a local ethics committee (approval no. 88-210). The LDL (4.5$7.5 \mathrm{mg}$ protein) from three patients was pooled and analyzed by procedures described elsewhere (Wang \& Powell 1991, Wang et al. 1992). The antioxidant propyl gallate $(50 \mu \mathrm{M})$ was present during preparation and extraction of LDL (Folch et al. 1957). After extraction solvents were evaporated under argon, samples were redissolved in $0.2 \mathrm{~mol} / 1$ sodium methoxide in methanol, and 200 ng methyl 14-hydroxy-10,13-nonadecadienoate (14h-19:2 Me) (prepared from nonadecadienoic acid (Funk \& Powell 1985)) were added as internal standard. In one experiment, classes of lipids from the pooled LDL of two patients (3-5 $\mathrm{mg}$ protein) were separated on aminopropyl cartridges (Kaluzny et al. 1985) before sodium methoxide treatment. After $1 \mathrm{~h}$ at room temperature, the solution was neutralized with acetic acid, evaporated to $0.3 \mathrm{ml}$, and diluted with $1.7 \mathrm{ml} 50 \mathrm{mmol} / 1$ Tris-buffer $(\mathrm{pH} 7 \cdot 0)$. Transesterified acids were extracted three times with dichloromethane, solvents were evaporated under argon, and residues were redissolved in ethyl acetate: hexane $(3: 47 \mathrm{v} / \mathrm{v})$ and applied to silicic acid (Biosil HA) columns. Fatty acid and hydroxy acid methyl esters, eluted with ethyl acetate:hexane $(3: 47 \mathrm{v} / \mathrm{v})$, were analyzed by reverse-phase HPLC (RP-HPLC) on a $\mathrm{C}_{18}$ Nucleosil column $(2 \cdot 1 \times 100 \mathrm{~mm}, 5 \mu \mathrm{m}$ particles) (Macherey-Nagel Co, Düran, Germany) using a gradient of $30-85 \%$ acetonitrile in water $(\mathrm{v} / \mathrm{v})$ supplemented with $0.01 \%$ acetic acid. A Hewlett Packard model 1090 liquid chromatograph with a built-in model 1040 diode array detector was used for these analyses and light absorbance of the column effluent was monitored between 200 and $600 \mathrm{~nm}$. Hydroxy acid methyl esters eluted between 17 and $21 \mathrm{~min}$ were collected, dried under argon, redissolved in methanol and hydrogenated over platinum dioxide for $90 \mathrm{~s}$. The catalyst was removed by centrifugation and samples were dried under argon and treated with $10 \mu \mathrm{l} N$-bistrimethylsilyltrifluoroacetamide mixed with $10 \mu \mathrm{l}$ pyridine at $50{ }^{\circ} \mathrm{C}$ for $60 \mathrm{~min}$. They were then subjected to selected 
Table 1 SIM of LDL hydroxy acids. Monohydroxy acid methyl esters obtained from LDL were measured after reduction of double bonds with $\mathrm{H}_{2} / \mathrm{PtO}_{2}$ and conversion to trimethylsilyl ether derivatives. Two ions were monitored for each hydroxyacid as indicated below

\begin{tabular}{|c|c|c|c|c|c|c|c|}
\hline & \multicolumn{6}{|c|}{ Hydroxy acids } & \multirow{2}{*}{$\begin{array}{l}\text { Correction ratio } \\
(\mathrm{m} / \mathrm{z} 329: \mathrm{m} / \mathrm{z} \text { X) }\end{array}$} \\
\hline & $9 h-18: 0$ & 13h-18:0 & $5 h-20: 0$ & 12h-20:0 & 15h-20:0 & 14h-19:0 & \\
\hline \multicolumn{8}{|c|}{ Ion (m/z) } \\
\hline 173 & & $x$ & & & $x$ & $x$ & \\
\hline 203 & & & $X^{*}$ & & & & $1 \cdot 3$ \\
\hline 215 & & & & $x$ & & & \\
\hline 229 & $x$ & & & & & & \\
\hline 259 & $X^{*}$ & & & & & & 11 \\
\hline 301 & & & & $X^{*}$ & & & $0 \cdot 6$ \\
\hline 313 & & & $x$ & & & & \\
\hline 315 & & $X^{*}$ & & & & & 15 \\
\hline 329 & & & & & & $X^{*}$ & \\
\hline 343 & & & & & $X^{*}$ & & $1 \cdot 2$ \\
\hline
\end{tabular}

*SIM trace is shown in Fig. 2.

9h-18:0, 9-hydroxyoctadecanoic acid; 13h-18:0, 13-hydroxyoctadecanoic acid; 5h-20:0, 5-hydroxyeicosanoic acid; 12h-20:0, 12-hydroxyeicosanoic acid; 15h-20:0, 15-hydroxyeicosanoic acid, 14h-19:0, 14-hydroxynonadecanoic acid.

ion monitoring (SIM) analysis on a Hewlett Packard $5890 \mathrm{~A}$ gas chromatograph, connected to a Hewlett Packard 5790B quadrupole mass spectrometer with $70 \mathrm{eV}$ electron impact ionization. An Ultra-2 capillary column $(25 \mathrm{~m} \times 0.2 \mathrm{~mm})$ was used at $235^{\circ} \mathrm{C}$.

\section{Semiquantitative analyses of hydroxy acids}

The concentrations of hydroxy acids in LDL were calculated from the ratio of the ion labeled with an asterisk in Table 1 to the ion at $\mathrm{m} / \mathrm{z} 329$ in $14 \mathrm{~h}-19: 0 \mathrm{Me}$. In order to compensate for differences in relative abundance of the ions labeled with an asterisk and that of $\mathrm{m} / \mathrm{z} 329$ a correction ratio (Table 1) was determined by analyzing equal amounts of the authentic reference compound and 14h-19:0 Me.

\section{Preparation of $P^{35}$ S]methionine-labeled $C B P(1-450)$ and SRC-1}

pcDNA3-CBP(1-450), encoding amino acids 1-450 of $\mathrm{CBP}$, was prepared from pcDNA3-CBP by restriction cutting with EcoRI. The resulting CBP fragment was ligated to pcDNA3 (Invitrogen) previously cut with EcoRI. The construct was checked for orientation of the insert and used as template to prepare $\left[{ }^{35} \mathrm{~S}\right]$ methioninelabeled $\mathrm{CBP}(1-450)$ by in vitro transcription and translation, using the TNT Coupled Reticulocyte Lysate System (Promega). pcDNA3-SRC-1 was similarly used to prepare $\left[{ }^{35} \mathrm{~S}\right]$ methionine-labeled SRC-1.

\section{Glutathione S-transferase (GST)-pulldown assay}

We used the GST-pulldown assay (DiRenzo et al. 1997, Krey et al. 1997) to identify ligands of PPAR $\gamma$. To generate GST-PPAR $\gamma$ fusion protein, mouse PPAR $\gamma$ cDNA was inserted into the NcoI-HindIII sites of pGEXKG, and PPAR $\gamma$ was then expressed in E. coli, strain Y1090. The bacteria were lysed by sonication in buffer (50 mmol/1 Tris- $\mathrm{HCl} \mathrm{pH} 7 \cdot 4,1.5 \mathrm{mmol} / 1$ EDTA, $10 \%$ glycerol, $\quad 0.4 \mathrm{~mol} / 1 \mathrm{NaCl}, \quad 0.1 \mathrm{mmol} / 1$ dithiothreitol (DTT) ) containing the following protease inhibitors: $0.5 \mathrm{mmol} / 1$ polymethylsulfonyl fluoride, $1 \mathrm{mmol} / 1 \mathrm{benza}-$ midine, $10 \mu \mathrm{g} / \mathrm{ml}$ leupeptin, $10 \mu \mathrm{g} / \mathrm{ml}$ antipain and $10 \mu \mathrm{g} / \mathrm{ml}$ aprotinin. The lysates were centrifuged at $100000 \mathrm{~g}$ for $60 \mathrm{~min}$ in a SW 41 rotor in a Beckman L8-70 M ultracentrifuge (Fullerton, CA, USA), and the recombinant fusion protein was immobilized on GSHSepharose beads. These beads were then incubated with ligands in $100 \mu \mathrm{l}$ CHAPS buffer $(8 \mathrm{mmol} / \mathrm{l}$ Tris- $\mathrm{HCl} \mathrm{pH}$ $7 \cdot 4,0 \cdot 12 \mathrm{~mol} / 1 \mathrm{KCl}, 8 \%$ glycerol, $4 \mathrm{mmol} / 1 \mathrm{DTT}$, and $0.5 \% \mathrm{CHAPS}$ ) for $30 \mathrm{~min}$ at room temperature. Approximately $0 \cdot 1 \mu \mathrm{Ci} \quad\left[{ }^{35} \mathrm{~S}\right]$ methionine-labeled $\mathrm{SRC}-1$ or $\left[{ }^{35} \mathrm{~S}\right]$ methionine-labeled CBP(1-450) was then added and the incubation was continued for another hour at $4{ }^{\circ} \mathrm{C}$. Excess labeled coactivator protein was washed away with CHAPS buffer after the incubation. After addition of SDS sample buffer, the samples were boiled for $2 \mathrm{~min}$, and proteins were separated on 7.5\% SDS-PAGE gels. Radioactivity was detected by autoradiography.

\section{Transfection experiments}

Expression plasmids encoding GAL4-DBD (amino acids 1-147)/mPPAR $\gamma$-LBD (amino acids 174-475) (m indicates mouse) or GAL4-DBD (amino acids 1-147) as well as the reporter plasmid containing four GAL4 binding sites (17-mer) linked to the adenovirus E1b minimal promoter and a luciferase reporter gene are described in Forman et al. (1995) and DiRenzo et al. (1997). Another reporter 


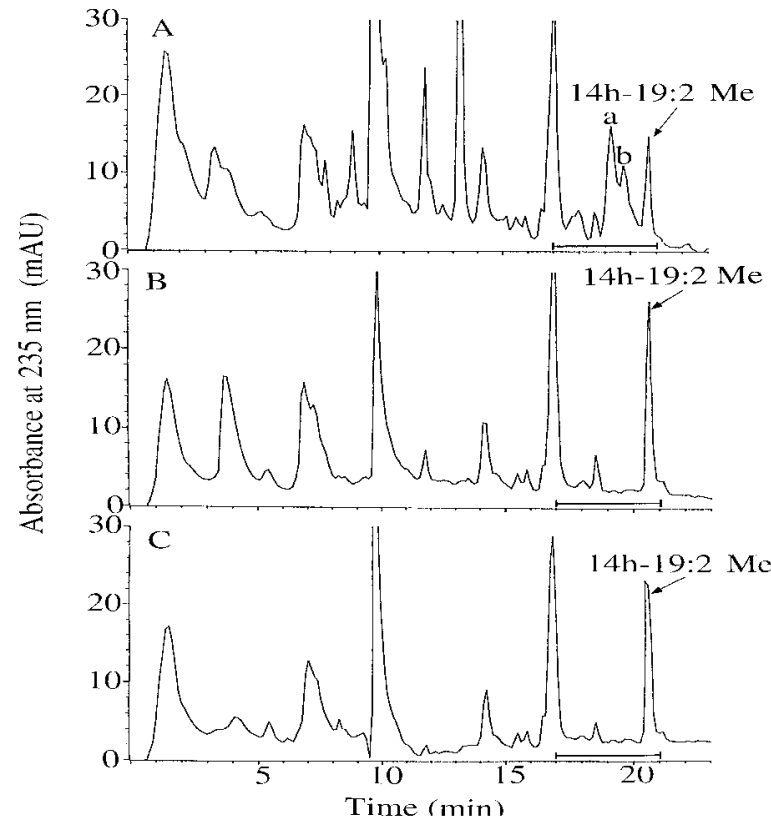

Figure 1 HPLC analysis of hydroxy acids from plasma LDL of patients with intermittent claudication. Folch extracts (see Materials and Methods) of LDL were fractionated on aminopropyl cartridges (Kaluzny et al. 1985). The phospholipid (A), triglyceride (B) and cholesterol ester (C) fractions were mixed with $200 \mathrm{ng}$ internal standard 14h-19:2 Me and treated with sodium methoxide. Fatty acid methyl esters were purified by silicic acid column chromatography and analyzed by RP-HPLC on a $\mathrm{C}_{18}$ Nucleosil column using a gradient of $30-35 \%$ acetonitrile in water $(\mathrm{v} / \mathrm{v})$. Hydroxy acid methyl esters were eluted between 17 and 21 min. Component ' $a$ ' contained 9- and 13-HODE and component ' $b$ ' contained 5-, 12- and 15-HETE. 14h-19:2 Me, internal standard.

construct, acyl-CoA oxidase-peroxisome proliferator response element-thymidine kinase-luciferase ((AOxPPRE) ${ }_{3}$-TK-luciferase) (Ricote et al. 1998b), contained three copies of the acyl-CoA oxidase PPRE upstream of the Herpes-simplex virus TK promoter. Expression vectors containing the cytomegalovirus IE promoter/ enhancer upstream of wild-type mouse PPAR $\gamma$ (pCMX$\operatorname{mPPAR} \gamma)$ and human $\operatorname{RXR} \alpha(\operatorname{pCMX}-\operatorname{hRXR} \alpha)$ were obtained from Dr R M Evans (The Salk Institute, La Jolla, CA, USA). pcDNA3-mCBP was provided by Dr R Goodman (Oregon Health Science University, Portland, OR, USA) and pcDNA3-hSRC-1 was prepared as described (Torchia et al. 1997). pcDNA3-mTIF2 and pcDNA3-mp/CIP were kindly provided by Dr J Torchia, London Regional Cancer Center, London, Ontario, Canada. RAW 264.7 murine macrophages, grown in 24-well plates, were transfected with $0.5 \mu \mathrm{g}$ each of reporter plasmid and expression plasmid using the Lipofectamine Plus reagent (Gibco-BRL). PPAR $\gamma$ ligands dissolved in ethanol (or just ethanol) were added $3-5 \mathrm{~h}$ after the addition of DNA to RAW $264 \cdot 7$ cells. CV-1 cells

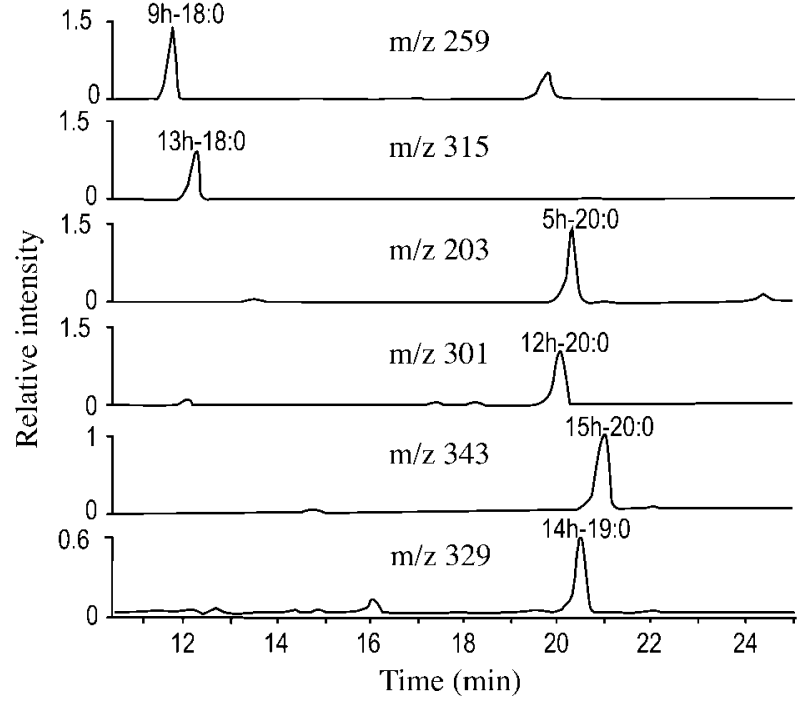

Figure 2 SIM analysis of LDL hydroxy acids. Hydroxy acid methyl esters were purified by RP-HPLC, hydrogenated, converted to trimethylsilyl ether derivatives and analyzed by gas chromatography/ mass spectrophotometry (SIM mode) on a $25 \mathrm{~m}$ Ultra-2 capillary column at $235{ }^{\circ} \mathrm{C} .9$ h-18:0, 9-hydroxyoctadecanoic acid; 13h-18:0, 13-hydroxyoctadecanoic acid; 14h-19:0, 14-hydroxynonadecanoic acid; 5h-20:0, 5-hydroxyeicosanoic acid; 12h-20:0, 12-

hydroxyeicosanoic acid; 15h-20:0, 15-hydroxyeicosanoic acid.

were transfected with $0 \cdot 25 \mu \mathrm{g}$ each of reporter plasmid and expression plasmid DNA using the calcium phosphate precipitation method. Next morning, CV-1 cells were washed in PBS and fresh media containing PPAR $\gamma$ ligands dissolved in ethanol (or just ethanol) were added. Luciferase activity of cell homogenates was measured 23-26 h after ligand addition using a Monolight 3010 analytical luminometer (Analytical Luminiscence Laboratory, Sparks, MD, USA).

\section{Statistical analyses}

Statistical analyses were performed using Student's $t$-test.

\section{Results}

\section{LDL analyses}

RP-HPLC chromatograms of hydroxy acids in the cholesterol ester, triglyceride and phospholipid fractions of LDL from two of the eight male patients, aged 45-65 years, with intermittent claudication are shown in Fig. 1. Components were collected within a time interval (17$21 \mathrm{~min}$ ) set by the retention times of authentic 13-HODE and 14-hydroxy-10,13-nonadecadienoate respectively. With the exception of the minor compounds eluted at 15.5 and $15.8 \mathrm{~min}$, no other components displayed UV spectra indicating the presence of conjugated dienes. The 


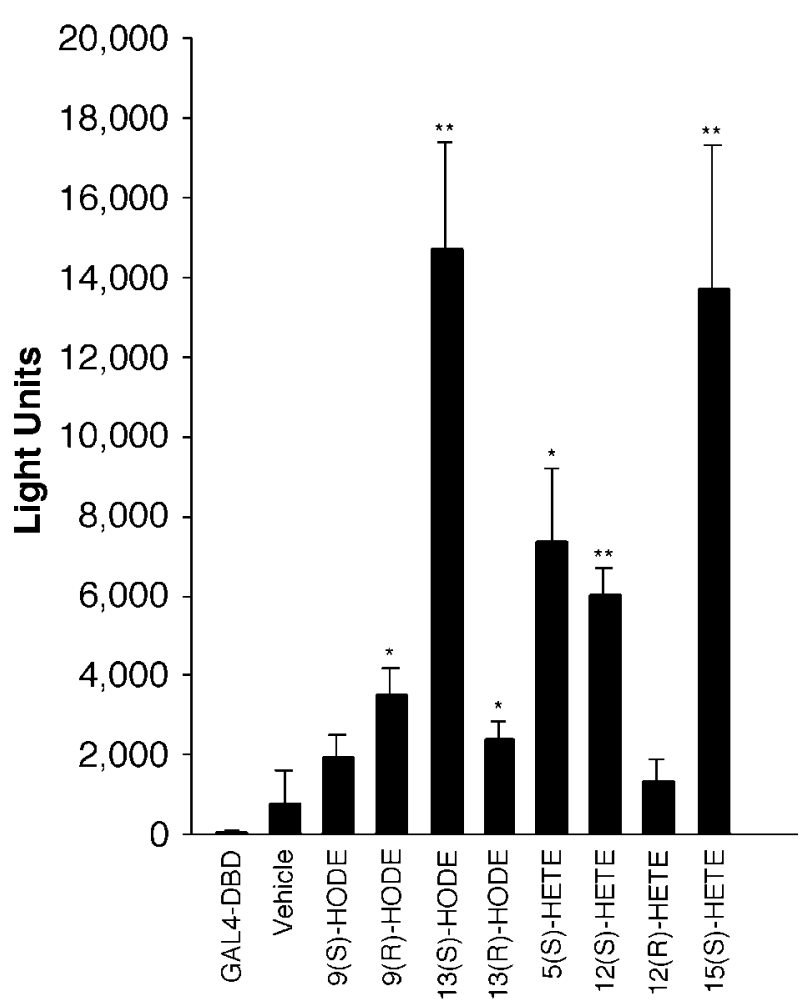

Figure 3 Activation of PPAR $\gamma$ by eicosanoids and HODEs. RAW 264.7 murine macrophages were transfected with $0.5 \mu \mathrm{g}$ $\left.(\mathrm{GAL} 4)_{\mathrm{UAS}}\right)_{4}$ E1b Luc reporter plasmid and $0.5 \mu \mathrm{g}$ of an expression vector encoding GAL4-DBD/mPPAR $\gamma$ LBD as shown. The transfected cells were treated with $5 \mu \mathrm{mol} / \mathrm{l}$ of the indicated compounds dissolved in ethanol. Control cells were treated with just ethanol. After $23-26 \mathrm{~h}$ the cells were harvested, and luciferase activity was determined. The bars represent means \pm S.D. of triplicate analyses $\left({ }^{*} P<0 \cdot 05,{ }^{*} P<0 \cdot 01, n=3\right)$. Similar results were obtained in three separate experiments. A control experiment with GAL4-DBD alone gave less than $10 \%$ of the luciferase activity of the control cells treated with just ethanol.

components that eluted before and after the designated time interval may have been fatty acids that lacked a conjugated diene or other products of similar polarity. The phospholipid fraction contained the largest amount of LDL monohydroxy acids (Fig. 1A) and smaller amounts were detected in the triglyceride fraction (Fig. 1B). The cholesterol ester fraction did not contain detected amounts of monohydroxy acids (Fig. 1C).

SIM was performed on methyl ester and trimethylsilyl ether derivatives of hydrogenated LDL fatty acids (Fig. 2). Ions characteristic for 9-HODE and 13-HODE as well as 5-, 12- and 15-HETEs were monitored simultaneously (see Table 1). The following semiquantitative mean values were obtained from two separate analyses of LDL pooled from three patients in each case; 9-HODE, 9.3 $\mu \mathrm{g} / \mathrm{g} \mathrm{LDL}$ protein; 13-HODE, $10 \cdot 5 \mu \mathrm{g} / \mathrm{g}$ LDL protein; 5-HETE, $0.34 \mu \mathrm{g} / \mathrm{g}$ LDL protein; 12-HETE, $0 \cdot 14 \mu \mathrm{g} / \mathrm{g}$ LDL protein; and 15-HETE $0.38 \mu \mathrm{g} / \mathrm{g}$ LDL protein.

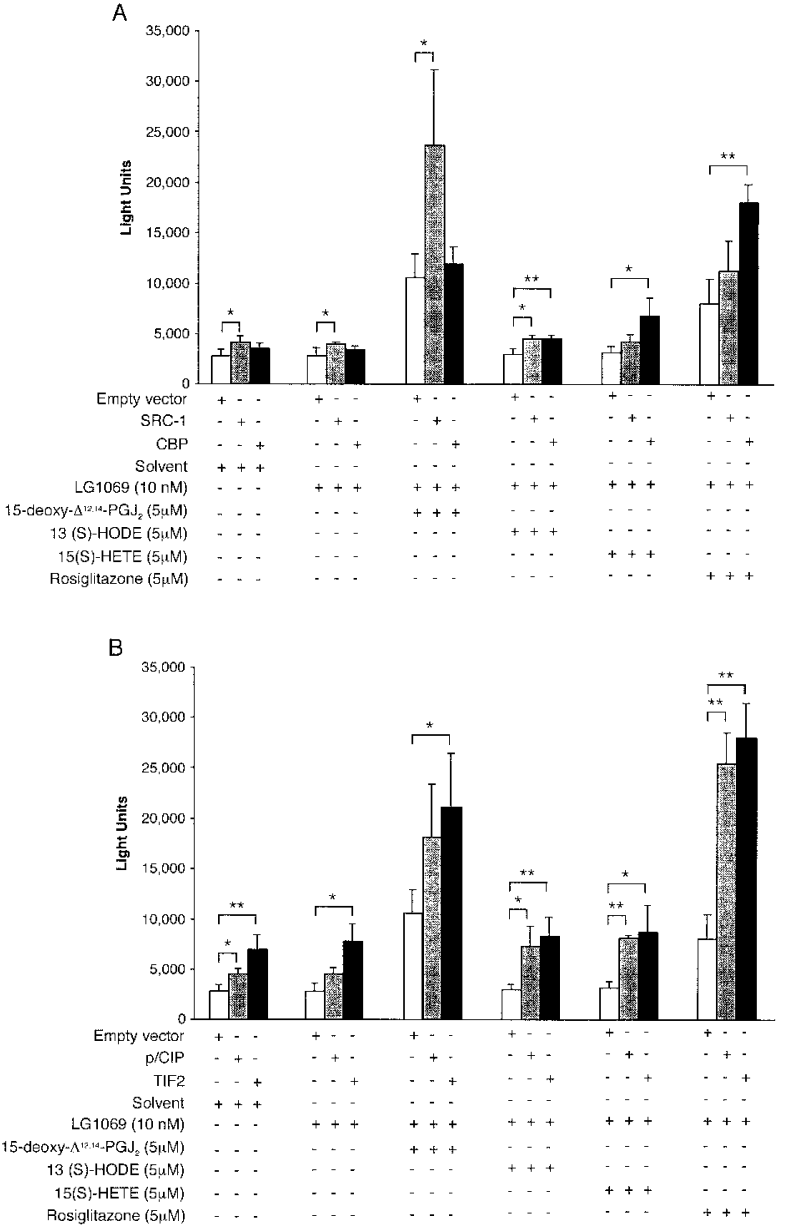

Figure 4 HETEs and HODEs appear to selectively recruit CBP whereas 15 -deoxy- $\left.\Delta^{12,14}-\mathrm{PG}\right)_{2}$ apparently recruits SRC-1 to $\mathrm{PPAR} \gamma / \mathrm{RXR} \alpha$ heterodimers. CV-1 cells were transfected with $0 \cdot 25 \mu \mathrm{g}$ (AOx-PPRE) - $_{3}$-TK-luciferase reporter plasmid plus $0.25 \mu \mathrm{g}$ pCMX-mPPAR $\gamma$ and pCMX-hRXR $\alpha$ plasmids. The cells were also transfected with $0.25 \mu \mathrm{g}$ pcDNA3-hSRC-1 or $0.25 \mu \mathrm{g}$ pcDNA3-mCBP (A), and with $0 \cdot 25 \mu \mathrm{g}$ pcDNA3-mTIF2 or $0 \cdot 25 \mu \mathrm{g}$ pcDNA3-mp/CIP (B). pcDNA3 without insert was used as control. After transfection, the cells were treated with $10 \mathrm{nmol} / \mathrm{l}$ LG1069 and either 15-deoxy- $\left.\Delta^{12,14}-\mathrm{PGJ}_{2}(15 \mathrm{~d}-\mathrm{PG})_{2}\right), 13(\mathrm{~S})$-HODE, $15(\mathrm{~S})$-HETE or rosiglitazone each at $5 \mu \mathrm{mol} / \mathrm{l}$. The cells were harvested after $24 \mathrm{~h}$, and assayed for luciferase activity. The bars represent means \pm S.D. of triplicate samples and are representative of three independent experiments $\left({ }^{\star} P<0 \cdot 05,{ }^{*} P<0 \cdot 01, n=3\right)$.

\section{HODEs and HETEs activate PPAR $\gamma$ in vivo}

Activation of PPAR $\gamma$ was studied in transient transfection experiments using GAL4-DBD/PPAR $\gamma$ LBD fusion protein and a reporter plasmid containing four copies of GAL4-DNA binding site linked to an adenovirus E1b minimal promoter and a luciferase reporter gene. RAW 264.7 murine macrophages were transfected and incubated with monohydroxy acids $(5 \mu \mathrm{mol} / \mathrm{l})$ for $24 \mathrm{~h}$. The greatest luciferase activity (Fig. 3) was observed for 


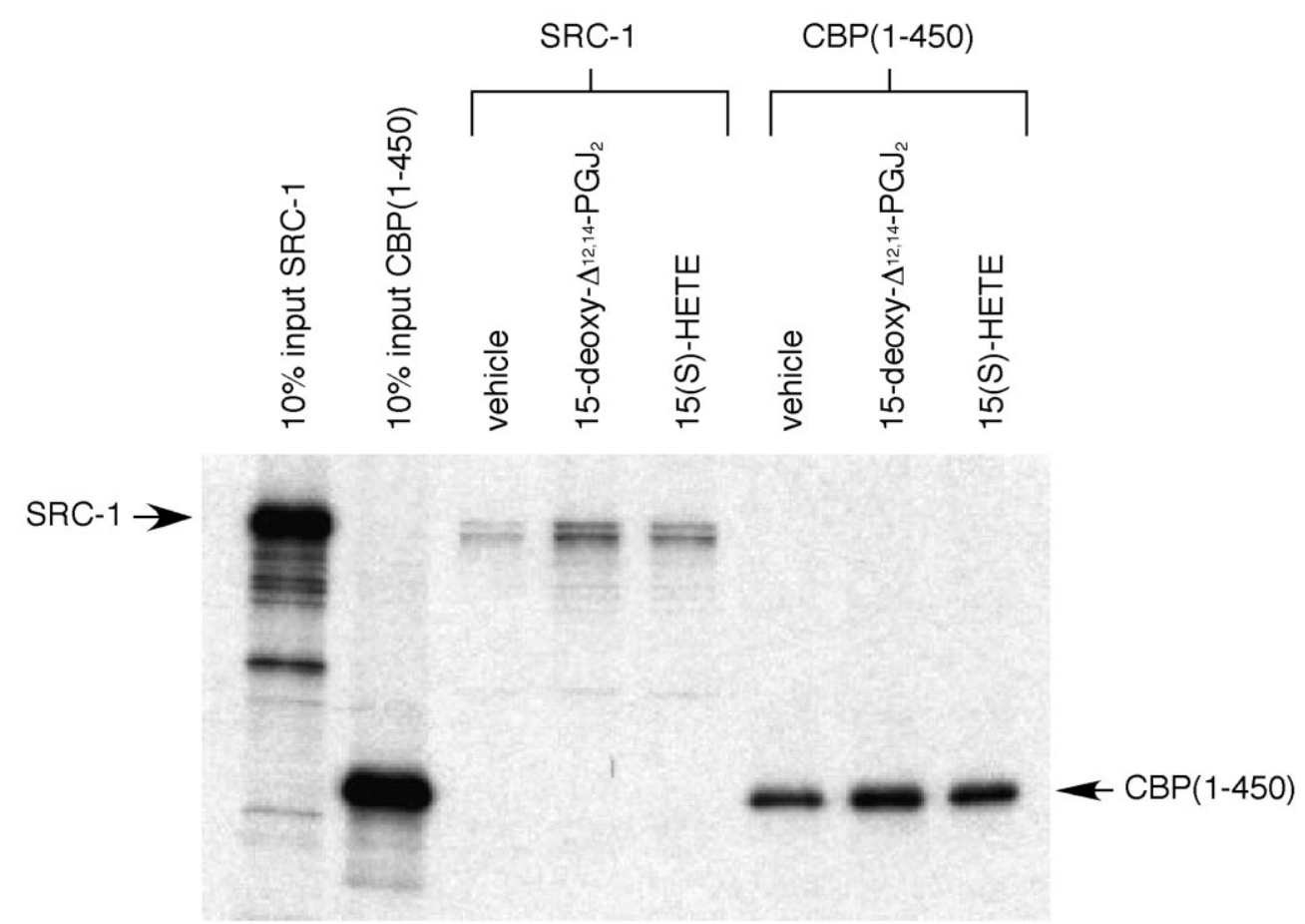

Figure 5 Ligand-independent interaction of CBP(1-450) and mPPAR $\gamma$. GST-PPAR $\gamma$ fusion protein, immobilized on GSH-Sepharose beads, was incubated with $5 \mu \mathrm{mol} / \mathrm{l} 15$ (S)-HETE or $5 \mu \mathrm{mol} / \mathrm{I}$ 15 -deoxy- $\left.\Delta^{12,14}-\mathrm{PG}\right]_{2}$ for $30 \mathrm{~min}$ at room temperature and then with $\left[{ }^{35} \mathrm{~S}\right]$ methionine-labeled SRC- 1 or $\left.{ }^{35} \mathrm{~S}\right]$ methionine-labeled $\mathrm{CBP}(1-450)$ for $60 \mathrm{~min}$ at $4{ }^{\circ} \mathrm{C}$. Beads were washed, and the absorbed proteins were analyzed by SDS-PAGE and autoradiography.

13(S)-HODE and 15(S)-HETE (approximately 20-fold induction) whereas $5(\mathrm{~S})$-HETE and 12(S)-HETE gave close to 10 -fold induction.

\section{Differential activation of $P P A R \gamma / R X R a$ heterodimers by $C B P$ and $S R C-1$}

Transient cotransfection experiments were conducted to determine whether different PPAR $\gamma$ ligands exert disparate effects on coactivator recruitment. CV-1 cells were transfected with combinations of plasmids encoding PPAR $\gamma, \mathrm{RXR} \alpha, \mathrm{CBP}$, transcriptional mediator/ intermediary factor-2 (TIF2), p300/CBP/co-integratorassociated protein ( $\mathrm{p} / \mathrm{CIP}$ ) and SRC-1 as indicated in Fig. 4. The transfected cells were then treated with the RXR-specific ligand LG1069 (10 nmol/l) combined with one of the following compounds: 13(S)-HODE, 15(S)HETE, $15-$ deoxy- $\Delta^{12,14}-\mathrm{PGJ}_{2}$ or rosiglitazone $(5 \mu \mathrm{mol} / 1$ of each). Cells cotransfected with SRC-1 showed a substantially greater induction of luciferase activity by 15 -deoxy- $\Delta^{12,14}-\mathrm{PGJ}_{2}$ than control cells without coactivators (Fig. 4A). On the other hand, cotransfection with SRC-1 had very little effect on reporter gene activation induced by $13(\mathrm{~S})-\mathrm{HODE}, 15(\mathrm{~S})$-HETE or rosiglitazone whereas cotransfection with CBP led to a marked increase in reporter gene activity induced by $13(\mathrm{~S})$-HODE, 15(S)HETE and rosiglitazone (Fig. 4A). Cells cotransfected with TIF2 or $\mathrm{p} / \mathrm{CIP}$ showed a significant increase in activation of luciferase activity by all ligands as compared with control cells without coactivators (Fig. 4B), and there was no apparent preference for any of the coactivators used (Fig. 4B).

\section{$C B P(1-450)$ interacts with $P P A R \gamma$ in vitro}

In order to assess the characteristics of the hydroxy acid-induced PPAR $\gamma / \mathrm{CBP}$ interactions that occur during transcriptional activation, an in vitro interaction (GSTpulldown) assay was used. In this assay, the binding of $\left[{ }^{35}\right.$ S $]$ methionine-labeled SRC-1 or ${ }^{35}$ S $]$ methioninelabeled $\mathrm{CBP}(1-450)$ to GST-PPAR $\gamma$ fusion protein immobilized on GSH-Sepharose beads was analyzed in the presence of potential ligands. $\operatorname{CBP}(1-450)$ bound to PPAR $\gamma$ irrespectively of whether $15-$ deoxy- $\Delta^{12,14}-\mathrm{PGJ}_{2}$ or 15(S) HETE was added or not (Fig. 5). SRC-1 binding, a positive control for ligand-induced coactivator binding, only occurred in the presence of ligands. 


\section{Discussion}

Lipoxygenase-catalyzed oxidation of LDL appears to be important in the pathogenesis of atherosclerosis (Rankin et al. 1991, Folcik \& Cathcart 1994). Furthermore, $\operatorname{PPAR} \gamma$ and 15-lipoxygenase have both been found to localize in atherosclerotic plaques (Yla-Herttuala et al. 1990, Ricote et al. 1998a). In the light of that, we conducted experiments to determine the amounts of potential lipoxygenase-formed hydroxy acids in LDL from patients with intermittent claudication. Semiquantitative analyses of HODEs (9-11 $\mu \mathrm{g} / \mathrm{g}$ LDL protein) and HETEs $(0 \cdot 1-0 \cdot 4 \mu \mathrm{g} / \mathrm{g}$ LDL protein) were performed. Similar levels of HODEs as observed before (Jira et al. 1998) were found in LDL from the 45-65 years old atherosclerotic male patients. These levels are probably sufficient for substantial activation of $\operatorname{PPAR} \gamma$ within the isolated environment of atherosclerotic plaques, considering that HODE and HETE concentrations of 1.4 and $1.6 \mu \mathrm{g} / \mathrm{ml}$ $(5 \mu \mathrm{mol} / \mathrm{l})$ respectively, were sufficient to activate PPAR $\gamma$ in our transfection assays. The 15-lipoxygenase products 13(S)-HODE and 15(S)-HETE were the most efficacious hydroxy acids in those assays (Fig. 3).

Some differences in the PPAR $\gamma$ activation induced by hydroxy acids in macrophages as compared with CV-1 cells are apparent: the 15-lipoxygenase products 13(S)HODE and 15(S)-HETE were most potent in macrophages (Fig. 3), whereas 9-HODE was most potent in CV-1 cells (Nagy et al. 1998). These differences might reflect cell-specific differences in the expression of PPAR $\gamma$-modulating proteins, such as coactivators or corepressors.

The coactivator protein CBP is involved in PPAR $\gamma$ activation (Smith et al. 1996, Jenster et al. 1997, Mizukami \& Taniguchi 1997, Westin et al. 1998) and interacts with nuclear receptors via short LXXLL domains (LXDs) (McInerney et al. 1996, Heery et al. 1997). To study the binding of CBP to liganded PPAR $\gamma$, the recruitment of a truncated form of CBP, spanning amino acids 1-450, was determined in a GST-pulldown assay (Fig. 5). This CBP mutant contains LXD1, which is contained within the nuclear receptor-interacting domain (Kamei et al. 1996) but lacks LXD2 in the SRC-1 interaction domain (McInerney et al. 1996). Interaction between SRC-1 and PPAR $\gamma$ served as a positive control. CBP $(1-450)$ bound PPAR $\gamma$ in a ligand-independent manner whereas SRC-1 was recruited by PPAR $\gamma$ when liganded to either 15 -deoxy- $\Delta^{12,14}-\mathrm{PGJ}_{2}$ or 15 (S)-HETE (Fig. 5).

Our transfection data indicate that the coactivators SRC-1 and CBP were differentially affected by different PPAR $\gamma$ ligands. However, p/CIP and TIF2 were both recruited to liganded receptor equally well in the presence of the different ligands (Fig. 4B). An obvious difference between the GST-pulldown results (Fig. 5) and the transfection data (Fig. 4) was observed for 15(S)-HETE, which in GST-pulldown induced SRC-1 binding to
$\operatorname{PPAR} \gamma$ even though no significant potentiation by SRC-1 was observed in transfection experiments. This discrepancy could be due to the fact that the GSTpulldown assay uses PPAR $\gamma$ which is not heterodimerized to RXR $\alpha$ and not bound to DNA, whereas in transfection assays PPAR $\gamma / \mathrm{RXR} \alpha$ heterodimers are DNA-bound.

An implication of our results is that different PPAR $\gamma$ ligands exert disparate effects on the recruitment of coactivator proteins. This in turn may be due to differences in the ligand-induced conformational change of PPAR $\gamma / \operatorname{RXR} \alpha$ heterodimers bound to DNA. 13(S)HODE and 15(S)-HETE caused a change that promotes interaction with CBP but not with SRC-1, whereas $15-$ deoxy- $\Delta^{12,14}-\mathrm{PGJ}_{2}$ apparently induces changes that attract SRC-1. It is not unlikely that such ligand-specific conformational control may also occur in other nuclear or plasma membrane-bound receptors.

In this investigation we have demonstrated the presence of several HODEs and HETEs in LDL from patients with clinical manifestations of atherosclerosis and shown that these compounds exert distinct and specific effects on gene expression mediated by the nuclear receptor PPAR $\gamma$. Although these effects might have relevance for the pathogenesis of athereosclerosis, no causal relationship should be concluded from the present results. The observations are, however, of interest as they suggest possible mechanisms for the atherogenic properties of oxidized LDL.

\section{Acknowledgements}

We thank Marie Waldén for skilful technical assistance, Kristina Loinder for making the $\mathrm{CBP}(1-450)$ construct, Cecilia Trinks for help with GST-pulldown experiments, and Gunnel Almroth, Britt Sigfridsson and Ylva Svensson for preparing LDL. This work was supported by grants from the Swedish Medical Research Council (03X-5914, 12X-12544, and 19X-6962), the Swedish Cancer Society (3930-B00-04 XBB) and from the County Council of Östergötland.

\section{References}

Boehm MF, Zhang L, Zhi L, McClurg MR, Berger E, Wagoner M, Mais DE, Suto CM, Davies JA, Heyman RA et al. 1995 Design and synthesis of potent retinoid X receptor selective ligands that induce apoptosis in leukemia cells. Journal of Medical Chemistry 38 $3146-3155$.

DiRenzo J, Söderström M, Kurokawa R, Ogliastro MH, Ricote M, Ingrey S, Hörlein A, Rosenfeld MG \& Glass CK 1997 Peroxisome proliferator-activated receptors and retinoic acid receptors differentially control the interactions of retinoid $\mathrm{X}$ receptor heterodimers with ligands, coactivators, and corepressors. Molecular Cell Biology 17 2166-2176.

Fitzpatrick FA \& Wynalda MA 1983 Albumin-catalyzed metabolism of prostaglandin $\mathrm{D}_{2}$. Identification of products formed in vitro. Journal of Biological Chemistry 258 11713-11718. 
Folch J, Lees M \& Sloane Stanley GHS 1957 A simple method for the isolation and purification of total lipids from animal tissues. Journal of Biological Chemistry 226 497-509.

Folcik VA \& Cathcart MK 1994 Predominance of esterified hydroperoxy-linoleic acid in human monocyte-oxidized LDL. Journal of Lipid Research 35 1570-1582.

Forman BM, Tontonoz P, Chen J, Brun RP, Spiegelman BM \& Evans RM 1995 15-deoxy- $\Delta^{12,}{ }^{14}$-prostaglandin $J_{2}$ is a ligand for the adipocyte determination factor PPAR $\gamma$. Cell 83 803-812.

Funk CD \& Powell WS 1985 Release of prostaglandins and monohydroxy and trihydroxy metabolites of linoleic and arachidonic acids by adult and fetal aortae and ductus arteriosus. Journal of Biological Chemistry $2607481-7488$.

Glass CK 1994 Differential recognition of target genes by nuclear receptor monomers, dimers, and heterodimers. Endocrine Reviews 15 391-407.

Green S 1995 PPAR: a mediator of peroxisome proliferator action. Mutation Research 333 101-109.

Havel RJ, Eder HA \& Bragdon JH 1955 The distribution and chemical composition of ultracentrifugally separated lipoproteins in human serum. Journal of Clinical Investigation 34 1345-1353.

Heery DM, Kalkhoven E, Hoare S \& Parker MG 1997 A signature motif in transcriptional co-activators mediates binding to nuclear receptors. Nature 387 733-736.

Jenster G, Spencer TE, Burcin MM, Tsai SY, Tsai MJ \& O’Malley BW 1997 Steroid receptor induction of gene transcription: a two-step model. PNAS 94 7879-7884.

Jiang C, Ting AT \& Seed B 1998 PPAR $-\gamma$ agonists inhibit production of monocyte inflammatory cytokines. Nature 391 82-86.

Jira W, Spiteller G, Carson W \& Schramm A 1998 Strong increase in hydroxy fatty acids derived from linoleic acid in human low density lipoproteins of atherosclerotic patients. Chemistry and Physics of Lipids 91 1-11.

Kaluzny MA, Duncan LA, Merritt MV \& Epps DE 1985 Rapid separation of lipid classes in high yield and purity using bonded phase columns. Journal of Lipid Research 26 135-140.

Kamei Y, Xu L, Heinzel T, Torchia J, Kurokawa R, Gloss B, Lin SC, Heyman RA, Rose DW, Glass CK et al. 1996 A CBP integrator complex mediates transcriptional activation and AP-1 inhibition by nuclear receptors. Cell 85 403-414.

Kikawa Y, Narumiya S, Fukushima M, Wakatsuka H \& Hayaishi O 1984 9-Deoxy- $\Delta^{9,12}-13,14$-dihydroprostaglandin $\mathrm{D}_{2}$, a metabolite of prostaglandin $\mathrm{D}_{2}$ formed in human plasma. PNAS $\mathbf{8 1}$ 1317-1321.

Kliewer SA, Lenhard JM, Willson TM, Patel I, Morris DC \& Lehmann JM 1995 A prostaglandin $\mathrm{J}_{2}$ metabolite binds peroxisome proliferator-activated receptor gamma and promotes adipocyte differentiation. Cell 83 813-819.

Krey G, Braissant O, L'Horset F, Kalkhoven E, Perroud M, Parker MG \& Wahli W 1997 Fatty acids, eicosanoids, and hypolipidemic agents identified as ligands of peroxisome proliferator-activated receptors by coactivator-dependent receptor ligand assay. Molecular Endocrinology 11 779-791.

McGuire JC, Richard KA, Sun FF \& Tracey DE 1985 Production of prostaglandin $\mathrm{D}_{2}$ by murine macrophage cell lines. Prostaglandins $\mathbf{3 0}$ 949-967.
McInerney EM, Tsai MJ, O'Malley BW \& Katzenellenbogen BS 1996 Analysis of estrogen receptor transcriptional enhancement by a nuclear hormone receptor coactivator. PNAS 93 10069-10073.

McIntyre TM, Ponstler AV, Silva AR, St Hilaire A, Xu Y, Hinshaw JC, Zimmerman GA, Hama K, Aoki J, Arai H et al. 2003 Identification of an intracellular receptor for lysophosphatidic acid (LPA): LPA is a transcellular PPAR $\gamma$ agonist. PNAS 100 131-136.

Mizukami J \& Taniguchi T 1997 The antidiabetic agent thiazolidinedione stimulates the interaction between PPAR $\gamma$ and CBP. Biochemical and Biophysical Research Communications 240 61-64.

Nagy L, Tontonoz P, Alvarez JG, Chen H \& Evans RM 1998 Oxidized LDL regulates macrophage gene expression through ligand activation of PPAR $\gamma$. Cell 93 229-240.

Rankin SM, Parthasarathy S \& Steinberg D 1991 Evidence for a dominant role of lipoxygenase(s) in the oxidation of LDL by mouse peritoneal macrophages. Journal of Lipid Research 32 449-456.

Ricote M, Huang J, Fajas L, Li A, Welch J, Najib J, Witztum JL, Auwerx J, Palinski W \& Glass CK 1998a Expression of the peroxisome proliferator-activated receptor $\gamma(\operatorname{PPAR} \gamma)$ in human atherosclerosis and regulation in macrophages by colony stimulating factors and oxidized low density lipoprotein. PNAS 95 7614-7619.

Ricote M, Li AC, Willson TM, Kelly CJ \& Glass CK 19986 The peroxisome proliferator-activated receptor- $\gamma$ is a negative regulator of macrophage activation. Nature 391 79-82.

Smith CL, Onate SA, Tsai MJ \& O'Malley BW 1996 CREB binding protein acts synergistically with steroid receptor coactivator-1 to enhance steroid receptor-dependent transcription. PNAS $\mathbf{9 3}$ 8884-8888.

Tontonoz P, Nagy L, Alvarez JG, Thomazy VA \& Evans RM 1998 $\operatorname{PPAR} \gamma$ promotes monocyte/macrophage differentiation and uptake of oxidized LDL. Cell 93 241-252.

Torchia J, Rose DW, Inostroza J, Kamei Y, Westin S, Glass CK \& Rosenfeld MG 1997 The transcriptional co-activator $\mathrm{p} / \mathrm{CIP}$ binds CBP and mediates nuclear-receptor function. Nature 387 677-684.

Wang T \& Powell WS 1991 Increased levels of monohydroxy metabolites of arachidonic acid and linoleic acid in LDL and aorta from atherosclerotic rabbits. Biochimica et Biophysica Acta 1084 129-138.

Wang T, Yu WG \& Powell WS 1992 Formation of monohydroxy derivatives of arachidonic acid, linoleic acid, and oleic acid during oxidation of low density lipoprotein by copper ions and endothelial cells. Journal of Lipid Research 33 525-537.

Westin S, Kurokawa R, Nolte RT, Wisely GB, McInerney EM, Rose DW, Milburn MV, Rosenfeld MG \& Glass CK 1998 Interactions controlling the assembly of nuclear-receptor heterodimers and co-activators. Nature 395 199-202.

Yla-Herttuala S, Rosenfeld ME, Parthasarathy S, Glass CK, Sigal E, Witztum JL \& Steinberg D 1990 Colocalization of 15-lipoxygenase mRNA and protein with epitopes of oxidized low density lipoprotein in macrophage-rich areas of atherosclerotic lesions. PNAS 87 6959-6963.

Received 10 January 2003

Accepted 23 January 2003 